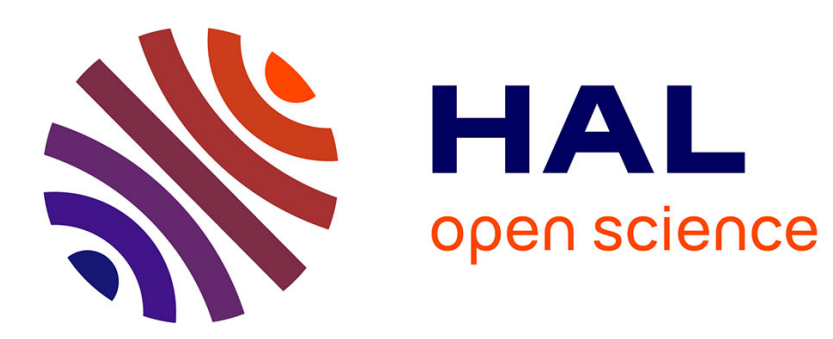

\title{
Ideology and scientific credibility: environmental policy in the American Pacific Northwest
}

\author{
Brent S. Steel, Denise Lach, Vijay A. Satyal
}

\section{To cite this version:}

Brent S. Steel, Denise Lach, Vijay A. Satyal. Ideology and scientific credibility: environmental policy in the American Pacific Northwest. Public Understanding of Science, 2006, 15 (4), pp.481-495. 10.1177/0963662506059261 . hal-00571084

\section{HAL Id: hal-00571084 \\ https://hal.science/hal-00571084}

Submitted on 1 Mar 2011

HAL is a multi-disciplinary open access archive for the deposit and dissemination of scientific research documents, whether they are published or not. The documents may come from teaching and research institutions in France or abroad, or from public or private research centers.
L'archive ouverte pluridisciplinaire HAL, est destinée au dépôt et à la diffusion de documents scientifiques de niveau recherche, publiés ou non, émanant des établissements d'enseignement et de recherche français ou étrangers, des laboratoires publics ou privés. 


\title{
Ideology and scientific credibility: environmental policy in the American Pacific Northwest
}

\author{
Brent S. Steel, Denise Lach and Vijay A. Satyal
}

In the later years of the twentieth century and into the twenty-first century, there has been an increasing emphasis among many decision-makers, interest groups, and citizens about the importance of science-based environmental policy. The assumption is that scientists can facilitate the resolution of public environmental decisions by providing scientific information to policymakers and the public, and by becoming more directly involved in policy arenas than they have traditionally been. However, at the same time, there are those who question the value of science, especially for ideological reasons. This study empirically examines the impact of ideology on attitudes toward science, scientific research, and scientists among various environmental policy participants. The data utilized to investigate these orientations were collected from surveys of five different groups involved in environmental policy and management in the Pacific Northwest including ecological scientists at universities and federal agencies; natural resource and environmental managers of state and federal programs; members of interest groups (e.g., environmental groups, industry associations, etc.); the "attentive public" (i.e., citizens who have participated in the environmental policy process); and the general public. Preliminary results reveal significant differences between liberals and conservatives in their orientations toward science, with selfidentified liberals generally more likely to see science and scientists as objective and conservatives having a contrary view.

\section{Introduction}

Recently, the Union of Concerned Scientists issued the report Scientific Integrity in Policymaking: An Investigation of the Bush Administration's Misuse of Science, which charges that "there is significant evidence that the scope and scale of the manipulation, suppression, and misrepresentation of science by the Bush Administration are unprecedented" (2004: 2). Of particular concern in this report is the role conservative ideology plays in the distortion of science. Many other observers, including social scientists, are also concerned about the misuse of science by ideologues as well. Jones (2002) criticizes the use of science for political goals and how bureaucracy often suppresses the dissemination of important and relevant information to the public, while Blockstein (2002) has warned that 
science is no longer immune to political pressures and suggests rules for scientists to follow, so that they are able to conduct their research independently and present findings without pressure and fear.

In this paper, we study the influence of ideology on attitudes toward science among ecological scientists, interest group representatives, natural resource managers, members of the public who have been involved in natural resource and environmental policy processes (which we will call the "attentive public"), and the general public. More specifically, we examine the impact of subjective ideological orientations among these five groups on attitudes toward the ability of scientists and the scientific method to produce unbiased and useful information in the design of environmental and natural resource policy. Ideologies are the set of ideals, principles, doctrines and myths that we have about how society is supposed to work. As Dolbeare and Medcalf have stated, "An ideology simplifies, organizes, evaluates, and gives meaning to what otherwise would be a very confusing world" (1993: 3). Political ideologies are those ideals and preferences we hold about how to allocate power and to what ends it should be used. Ideologies also serve "as guides to action" as well as "the glue that holds social groups together" (Dolbeare and Medcalf, 1993: 5).

The study was conducted in the context of the Long Term Ecological Research Program (LTER), a multi-site research effort that has been supported by the National Science Foundation since 1980. Data were collected from surveys of five different groups involved in environmental policy and management in the Pacific Northwest (primarily Oregon and Washington): ecological scientists at universities and federal agencies; natural resource and environmental managers of state and federal programs; members of interest groups (e.g., environmental groups, etc.); the "attentive public" (i.e., citizens who have participated in the environmental policy process in the region); and the general public in Oregon and Washington.

While this study concerns the American northwest, it has broader implications for understanding the role of scientists in other environmental and natural resource policy contexts with multiple stakeholders and participants. Many of the participants included in this research project were directly involved in the federal government's first major attempt at large-scale ecosystem management involving scientists, social scientists and managersPresident Clinton's Forest Ecosystem Management Team to manage late succession and old growth forests in America's west (FEMAT, 1993).

\section{Ideology and science}

As the scientific community has advanced our understanding of environmental issues and problems over the past three decades, it has become an ever more important participant in the policy process. When asked, many observers including scientists themselves, agree with Harmon's observation that, "We in modern society give tremendous prestige and power to our official, publicly validated knowledge system, namely science. It is unique in this position; none of the coexisting knowledge systems - not any system of philosophy or theology, not philosophy or theology as a whole-is in a comparable position" (Harmon, 1998: 116; cited in Shabecoff, 2000: 139). As Sarewitz and Pielke have observed, "Policy makers have called upon scientists to predict the occurrence, magnitude, and impacts of natural and human induced environmental phenomena ranging from hurricanes and earthquakes to global climate change and the behavior of hazardous waste materials" (2000: 11). 
The importance of science and scientists is reflected by the National Academy of Sciences, which was established by a Congressional charter in 1863 to "advise the federal government on scientific and technical matters" (National Academy of Sciences Charter). The Academy has been called on in recent years to research and to advise the government on environmental issues such as global warming, nuclear waste management and disposal, wildlife and fisheries management issues, and others.

While many scientists would agree that science is not value-free and that alternative sources of information beyond those produced by the application of conventional science to environmental problems can lead to the development of valid judgments about environmental issues, most would agree with scientist Roger Levien (1979) that basic science and applied scientific technology can play important and useful roles in the environmental policy process. Levien argues that there are three principal ways that science and technology can contribute to the effective management of environmental problems. First, scientists can help provide citizens and decision-makers a "common understanding" of the key dimensions of the environmental problem being addressed. Second, science can then "describe and invent options for the solution" of the environmental problem. According to Levien, the third and final way science can contribute in a major way to the resolution of environmental problems is by estimating "the consequences of proposed solutions" (1979: 48).

The privileging of science underlies many of the statutory requirements that form the basis of our environmental and natural resource management policies, including practices such as regional planning, cost-benefit analyses of policies and programs, environmental impact statement preparation, and risk assessments. These and other regulations, rules, and practices bring social and environmental values to a decision-making system that epitomizes rational and scientific problem-solving. Wildavsky further characterized the importance of science and scientists in the policy process:

Scientific evidence does matter. I notice that no mention is made of witchcraft as a rationale for regulation, but rather obeisance is made to science whether or not it is what matters. Nor does any reasonable person get up and say that his ideology or her world view requires inventing or denying dangers and to hell with the evidence. As long as science is the only publicly acceptable rationale, it matters. (Wildavsky, 1995: 5; cited in Alm, 1997-98: 256)

While there is strong support for the use of science in environmental and natural resource policy among scientists, policymakers and citizens alike, the traditional scientific approach —also called "normal science" by Thomas Kuhn (1970)—has come under increasing scrutiny in recent years. Some observers have called this the "science wars" in the Untied States (see Ross, 1996). The conventional model of science is seen by many as inadequate for various reasons. The combination of the complexity of the problems faced and the known limits of human measurement and analytical abilities come together to constrain the power of science in this area of governmental responsibility.

The postmodern approach of uncovering and criticizing the epistemological and ideological motivations of modern institutions has led to an alternative view of science. Following Lyotard's (1984) infamous definition of postmodernism as "incredulity toward meta-narratives," the acceptance of science as a process that results in authoritative and objective "facts" is challenged by local and experiential knowledge created in context by individuals with distinct ideologies. From this "post-normal" perspective, scientific data are understood as only one source of information and authority among the many sources involved in the policy process. Scientists, policymakers, and those affected by policy typically work together to construct the meaning of the policy and the relevant science, 
commonly ignoring the boundaries and authority of science assumed by many scientists. The value of scientific information can be considered to be entirely contingent on context, and non-scientific, political, personal, and ideological information can readily override scientific data in policymaking at many points (Funtowicz and Ravetz, 1992).

The emergence of this second understanding of the role of science in the policy process has been described by Shabecoff (2000: 139): "In recent decades, science has begun to slip from its lofty pedestal as it has become apparent that it is not adequate either to meet all the needs of humanity or to protect us from the dangers that science and technology themselves create." This model posits that science and scientists are considered just one of many sources of authority concerning natural resource management issues; that scientific information may itself be biased; and that other types of policy actors, information, and values are important in arriving at sensible public choices (e.g., Collingridge and Reeve, 1986; Ezrahi, 1980; Funtowicz and Ravetz, 1992; Ravetz, 1990).

Perhaps one of the most cynical critiques concerning science and the scientific method emanates primarily from politicians, interest groups, and public policy advocates who are politically conservative (Helvarg, 1994; Ross, 1996; Wilkinson, 1998). Paul and Anne Erhlich have labeled this anti-science attack from the political right "brownlash," a sentiment reflecting the belief that most scientific research concerning the environment is badly biased and inclined to overstate risks. According to Erhlich and Erhlich (1996), some of the authors that are critical of environmental science as viewed from this perspective include Gregg Easterbrook (1995), Stephen Budiansky (1995), Charles Mann and Mark Plummer (1995), Ronald Bailey (1993), Ben Bolch and Harold Lyons (1993), and Bjorn Lomborg's The Skeptical Environmentalist: Measuring the Real State of the World (1998), although Lomborg may not agree with being labeled as being politically on the right.

The following passage from Bolch and Lyons exemplifies this critical perspective toward environmental scientists (1993: 22-3):

The total environmental budgets of U.S. environmental advocacy groups alone are estimated to exceed a quarter of a billion dollars. With that kind of power and money at stake, no wonder new "threats" to mankind and the environment are discovered almost daily ... Scientists, especially academic scientists, are easily flattered with cocktail parties and press conferences, and can be counted on for a steady stream of new ideas. But even if no completely new problems are discovered, advancing techniques of scientific measurement guarantee that smaller and smaller levels of problem substances can be identified in an increasing number of things, such as polar ice or mother's milk.

As discussed in the introduction of this paper, some groups and observers, such as the Union of Concerned Scientists, have suggested that the George W. Bush administration has publicly promoted the use of science in environmental policies, yet in practice they ignore scientific evidence that doesn't support their conservative policy goals: they pressure scientists to produce results that support the administration's positions, and they use distorted statistics or "fuzzy math" to underestimate the benefits of environmental regulations and to overestimate the costs to industry (also see Devine, 2004).

Yet another critique of conventional science and scientists can be found among some on the left, including some environmental activists. While modern environmentalism has utilized and continues to make use of information supplied by science and scientists (e.g., Rachel Carson), there are those in the environmental movement who believe science is too often used for purposes destructive to the environment (Porritt, 2000). This critique finds its roots in the 1960s and 1970s when many people became concerned that the widespread use 
of some products of high technology — such as nuclear power, powerful pesticides and fungicides, genetic engineering, etc.-may pose serious threats to public health and the natural environment. A widely read example of this perspective is E.F. Schumacher's book Small is Beautiful: Economics as if People Mattered (1973). The current debate about the banning of genetically altered American foods and agricultural products by the European Community serves as an example of environmentalists acting on their belief that scientific research in this area can lead to much harm to the global ecosystem and to human health. British activist Jonathon Porritt has written along these critical lines in Seeing Green: The Politics of Ecology Explained (1985: 50). The following passage is telling in this regard:

There are those who would still have us believe that science itself is neutral, yet more and more it is being put to ideological uses to support particular interests, especially by those who already wield the power in our society. Science is simply not geared up to cope with the priority problems of humanity. It is the already privileged sectors of the developed economies that seem to get most of the benefits, spurred on by those whose interests can hardly be described as neutral. These "technocrats" have ensured that the principal measure of civilization should be technological progress rather than wisdom ...

What these different orientations toward science suggest is that, like all cultural phenomena, science is likely to be influenced by ideology, especially when it relates to environmental issues (Dunlap et al., 2001; Ehrlich and Ehrlich, 1996; Pierce et al., 1992; Ross, 1996). The main focus of this paper is to empirically investigate how ideological orientations influence attitudes toward science. For the purposes of this and earlier studies, we arrayed political ideologies on a continuum ranging from left or liberal to right or conservative. In general, those leaning to the left have ideals promoting liberty (individual freedom), equality (meritocracy), and fraternity (sense of common good) in the famous claim of the French Revolution. Those leaning to the right tend to have ideals elevating authority (order), hierarchy (organization), and property (private ownership) (Dolbeare and Medcalf, 1993). Without providing definitions, we ask respondents to identify where on this ideological continuum they consider themselves to be located. This method for self-assessment of political ideology has been used in multiple studies (e.g., Dunlap et al., 2001; Fleishman, 1986; Knight, 1993; Pierce et al., 1992). However, if used in another political system with more variation in ideological orientations when compared to the United States (e.g., presence of a viable socialist party), then different response patterns could be used (i.e., "very left" and "very right" as in the World Values Survey, European Value Surveys, and Eurobarometers).

Previous research revealed significant differences among scientists, natural resource managers, and the public about what constitutes science and the most suitable role for ecological science and scientists in the policy process (Lach et al., 2003; Steel et al., 2004). Interestingly, scientists were the most skeptical group about the objectivity of scientific research and about their ability to provide scientific answers to important environmental policy questions. They were also hesitant about engaging in the policy process. The public was found to be the most optimistic concerning the objectivity of science and the ability of scientists to effectively participate in the policy process. However, this research did not examine the impact of political ideology on attitudes toward science. Therefore, using data collected in the American northwest, we will examine the impact of ideology on orientations toward science and scientists among various policy actors. 


\section{Research location}

This study examines the role of science and scientists in the context of the Long Term Ecological Research Program (LTER), a multi-site research effort that has been supported by the National Science Foundation (NSF) since 1980. Ecological scientists at LTER sites around the country, Antarctica, and Puerto Rico are producing basic ecological knowledge that is changing the way scientists and lay people view the natural world (Luoma, 1999). They are also increasingly expected to participate with non-scientists in efforts to develop and even implement (sustainable) natural resource policies.

We were particularly interested in LTER scientists and research for several reasons. First, scientists working at LTER sites are conducting a variety of basic research projects that are funded by the NSF at least in part because they meet the criteria of "social relevance." Second, scientists at LTER sites represent a wide range of research organizations including colleges and universities, private research laboratories, and federal and state agencies. At the same time, LTER participants also represent a wide range of investigative and policy involvement from early-career scientists, managers, and public participants to "old hands" who have lived through shifts in natural resource policy, public attention, and public values. Finally, some LTER scientists collaborate with natural resource managers and the public in resource decisions and provide input to policymakers at local, state, and national levels. For example, scientists from the H.J. Andrews LTER site located in Blue River, Oregon, in the Oregon Cascade Mountains, participated directly in developing President Clinton's Northwest Forest Plan (FEMAT, 1993), and are currently active in the Cascade Center for Ecosystem Management, a federal government funded research program that involves cooperation between research scientists, forest managers, local environmental and industry groups, and public activists. Scientists at the H.J. Andrews LTER site have been involved in research for over 50 years, and the data and theories generated by these LTER scientists are applicable to other research locations-in both the national and international context.

\section{Methods}

In late 1999 and early 2000 (and mid 2000 for the general public survey), survey data were collected from random samples of different groups involved in environmental and natural resource management in the Pacific Northwest (primarily Oregon and Washington): natural resource scientists at universities and federal agencies (LTER scientists), managers of state and federal agencies (e.g., US Forest Service, Bureau of Land Management, Oregon Department of Forestry, etc.), members of natural resource organizations who have participated in public hearings and scoping activities concerning the management of public lands (e.g., environmental groups, industry associations), the "attentive public" (those having participated in a public hearing, providing a comment on proposed plans, or in some other way identifying themselves as aware of and participating in the decision processes of natural resource decision-making), and the general public in Oregon and Washington. Mail surveys were designed on the basis of 50 face-to-face interviews of representatives of each of the first four groups and responses to a pre-survey of government/university scientists. The general public version of the survey was conducted in June and July 2000 with a random sample of Oregon and Washington households. Three waves of mail surveys were sent along with a fourth telephone or e-mail reminder if necessary. Sample sizes and response rates are as in Table 1. 
Table 1. Sample sizes and response rates

\begin{tabular}{lcll}
\hline Sample & Sample size & Surveys returned & Response rate \\
\hline Scientist & 189 & 155 & $82 \%$ \\
Manager & 216 & 167 & $77 \%$ \\
Interest group representatives & 198 & 119 & $60 \%$ \\
Attentive public & 255 & 198 & $77 \%$ \\
General public & 1,861 & 973 & $52 \%$ \\
\hline
\end{tabular}

As with all surveys, question wording, refusals, and other implementation difficulties can result in error or bias. However, use of mail surveys in this project provides respondents time to read and reflect upon the intent and wording of each question before responding. Site and context specificity such as overall awareness of environmental issues, recent high visibility events related to natural resources (either natural or social), and the general sociopolitical context may also limit the scope for generalized inferences.

\section{Findings and discussion}

The first step in these analyses is to determine the general subjective ideological orientation of the various groups included in this study. As we discussed previously, we used a seven point scale with the following question and response categories: "On domestic policy issues, would you consider yourself to be ..." 1 = very liberal to $7=$ very conservative, with $4=$ moderate. Mean scores for the five groups, reported in Table 2, are significantly different (F-test significant at .000). Scientists are the group most likely to identify themselves as liberal with a mean score of 2.84, while the mean for the general public is the most conservative at 4.36-slightly to the right of moderate. Mean scores for managers were slightly left of center at 3.56 , while the mean score for the attentive public was close to moderate at 4.04 .

In order to determine orientations toward science and scientists, each respondent was asked their level of agreement or disagreement with a series of statements, which underlie or criticize many of the assumptions implicit in positivism, broadly construed. The introduction provided to the statements was as follows: "In recent years there has been increasing debate about what makes for reliable scientific findings that can be used with confidence to make important decisions. Please take a moment to let us know how you characterize science and the scientific process by indicating your level of agreement or disagreement with the

Table 2. Subjective ideological orientation of scientists, managers, NGO representatives, the attentive public, and the general public

\begin{tabular}{|c|c|c|}
\hline & Mean (s.d.) & \\
\hline Scientists & $2.84(1.17)$ & $n=153$ \\
\hline Managers & $3.56(1.12)$ & $n=164$ \\
\hline NGO representatives & $3.20(1.41)$ & $n=115$ \\
\hline Attentive public & $4.04(1.48)$ & $n=189$ \\
\hline General public & $4.36(1.53)$ & $n=968$ \\
\hline
\end{tabular}

F-test $=36.97, \mathrm{df}=4, p=.000$. 
following statements." The five statements concerning science that were included in all five surveys were developed on the basis of interviews and an exploratory survey with various government and university research scientists, philosophers of science, and social scientists (Thurstone scaling technique). In the exploratory survey, more than 50 university and government ecological scientists were provided with over 40 statements designed to represent or question positivistic perspectives of science. These 40 statements were drawn directly from the positivist Karl Popper's work The Poverty of Historicism (1961) and Objective Knowledge: An Evolutionary Approach (1972). Those statements that were uniformly identified as "positivist" in the exploratory study were included in the surveys utilized in this study. However, we only included five of these statements in the general public survey owing to space limitations.

Table 3 reports mean scores for these five statements controlling for ideological orientation. As discussed above, both observers on the left and right have had issues with science and the notion of positivism. For this analysis, we collapsed responses for the ideology scale into "liberal," "moderate," and "conservative" categories. Responses to the ideology scale were recoded as follows: "very liberal" and "liberal" = liberal; "very conservative" and "conservative" = conservative; and "slightly liberal," "moderate" and "slightly conservative" = moderate. We also tried collapsing responses by including "slightly liberal" with liberal and "slightly conservative" with conservative responses, but found that those respondents indicating they were "slightly" left or right of center did not significantly differ from moderates. Therefore, we classified these respondents as moderate in Table 3.

Because the focus of this paper is the impact of ideology on orientations of science, we examined difference in means within each of the five groups in Table 3; however, we will also examine the differences between groups in the forthcoming multivariate analyses. For the first statement in the table ("scientists are generally more objective than others involved in natural resource management decisions"), we find that there are no statistically significant differences between ideological groups for scientists, managers, and non-governmental organization (NGO) representatives. However, liberal members of the attentive and general publics are significantly more likely to agree with the statement than conservative respondents. A similar pattern was found for the closely related second statement ("science provides objective knowledge about the world"), with liberals in the attentive and general publics more likely to agree with the statement than their conservative counterparts. This same pattern also was found for NGO representatives; however, there are no significant differences between ideological groups among scientists and managers.

For the third statement included in the table ("nonscientists can make valid judgments about the same phenomena studied by scientists using different forms of rationality"), we find that conservative NGO representatives, and conservative attentive and general members of the public are significantly more likely to agree with this statement than their selfidentified liberal counterparts. However, once again we find no ideological difference among scientists and managers.

For the fourth statement suggesting that "scientific methods are inherently biased to support existing social power structures" (a charge that postmodern observers would support), we find statistically significant results for only two groups-NGO representatives and the attentive public. Liberals are slightly more likely to agree with this statement than conservatives. Ironically, for the final statement included in the table, which is somewhat similar to the fourth statement ("scientific findings are often biased by interpretations acceptable to the funding source"), conservative NGO representatives and members of the attentive public were significantly more likely than liberals to agree with this statement. 
Table 3. Subjective ideological orientation and attitudes toward science and scientists

\begin{tabular}{llll}
\hline & \multicolumn{2}{l}{ Subjective ideological orientation ${ }^{\mathrm{a}}$} & \\
\cline { 2 - 3 } & Liberal & Moderate & Conservative \\
mean & Mean & Mean \\
\hline
\end{tabular}

A. Scientists are generally more objective than others involved in natural resource management decisions ${ }^{\mathrm{b}}$

$\begin{array}{llll}\text { Scientists } & & \\ \text { Managers } & 2.54 & 2.36 & 2.25 \\ \text { NGOs } & 2.33 & 2.19 & 2.22 \\ \text { Attentive public** } & 3.14 & 2.92 & 3.00 \\ \text { General public** } & 3.48 & 2.81 & 2.48 \\ & 3.93 & 3.79 & 2.68\end{array}$

B. Science provides objective knowledge about the world

$\begin{array}{llll}\text { Scientists } & 2.75 & 2.80 & 2.75 \\ \text { Managers } & 3.23 & 3.35 & 3.34 \\ \text { NGOs*** } & 4.00 & 3.52 & 3.12 \\ \text { Attentive public*** } & 3.82 & 3.73 & 3.13 \\ \text { General public** } & 3.98 & 3.75 & 3.00\end{array}$

C. Nonscientists can make valid judgments about the same phenomena studied by scientists using different forms of rationality (e.g., experience)

$\begin{array}{llll}\text { Scientists } & 2.19 & 2.23 & 2.30 \\ \text { Managers } & 2.53 & 2.54 & 2.67 \\ \text { NGOs*** } & 2.69 & 2.81 & 3.70 \\ \text { Attentive public*** } & 2.66 & 3.12 & 3.62 \\ \text { General public*** } & 2.78 & 3.03 & 3.83\end{array}$

D. Scientific methods are inherently biased to support existing social power structures

$\begin{array}{llll}\text { Scientists } & 3.76 & 3.79 & 3.75 \\ \text { Managers } & 3.63 & 3.58 & 3.55 \\ \text { NGOs* } & 4.02 & 3.51 & 3.40 \\ \text { Attentive public** } & 3.86 & 3.66 & 3.33 \\ \text { General public } & 3.44 & 3.50 & 3.42\end{array}$

E. Scientific findings are often biased by interpretations acceptable to the funding source

$\begin{array}{llll}\text { Scientists*** } & 3.24 & 3.45 & 4.50 \\ \text { Managers } & 3.60 & 3.62 & 3.65 \\ \text { NGOs* } & 3.52 & 3.81 & 3.90 \\ \text { Attentive public*** } & 2.72 & 3.24 & 3.50 \\ \text { General public*** } & 2.88 & 3.26 & 3.61\end{array}$

\footnotetext{
a Responses to the ideology scale were recoded as follows: "very liberal" and "liberal" = liberal; "very conservative" and "conservative" = conservative; and "slightly liberal," "moderate" and "slightly conservative" = moderate.

${ }^{\mathrm{b}}$ Response categories were: $1=$ strongly disagree to $5=$ strongly agree.

${ }^{c}$ Significance levels for F-tests: $* p \leq .05 ; * * p \leq .01 ; * * * \leq .001$.

${ }^{\mathrm{d}}$ Sample sizes: scientists $=153$, managers $=164$, NGOs $=115$, attentive public $=189$, general public $=968$.
}

Conservative scientists and members of the general public were also more likely than their liberal counterparts to agree with this statement.

In general, we find that there are significant differences in attitudes about science within ideology groups. Members of NGOs, and the attentive and general public express more differences than scientists and managers among their ideological groups; those who describe themselves as liberal are more likely than those who describe themselves as conservative to agree that scientists are generally more objective than others involved in decision-making and that the scientific enterprise is itself biased to support the status quo. Conservative 
members of these groups are also more likely than liberal members to believe that nonscientists can make valid judgments without using scientific methods and that science can be biased by the funding sources. This last belief is shared by conservative scientists, which is the only significant difference among scientist and manager ideology groups.

The final analyses included in this study examine the effect of ideology on orientations toward science and scientists controlling for various independent variables. We use multivariate regression to examine the impact of ideology and other control variables on the five statements included in Table 3. Several sociodemographic factors are utilized as control variables including age in years, gender, and level of formal educational attainment. ${ }^{1}$ These variables have been found to be related to environmental attitudes and behavior in previous research, and we include them here so that we can control for their impact while examining the independent effect of ideology (see Dunlap and Michelson, 2001; Gardner and Stern, 2002; Pierce et al., 1992). We also control for the five research groups included in the study. For the series of dummy variables assessing each group, it is necessary to omit one dummy variable for the unbiased estimation of the equation. In the results presented here, we omit scientists. However, we conducted additional analyses omitting other groups as well and received consistent results. For ideology, we used the dummy variable created for Table 3. The dummy variable representing moderates is the category omitted. We also conducted additional analyses by omitting conservatives and liberals and found consistent results.

The models presented in Table 4 correspond to the five indicators (questions) displayed in Table 3. For all five models presented in Table 4, the F-statistic is significant, indicating that the specified structure statistically, constitutes an acceptable model. However, adjusted $R^{2}$ scores indicate that we are not explaining a great deal of variation in the dependent variable for each model (the range of adjusted $R^{2}$ scores is .04 to .19).

When examining the five models presented in Table 4, we find that at least one of the ideology dummy variables has a significant relationship in all but one model (Model D: "scientific methods are inherently biased to support existing social power structures"). After controlling for the various independent variables, we find the dummy variable for liberals is significant in models A, B and C. Self-identified liberals among the five research groups are significantly more likely than moderates and conservatives (we ran multiple models including and omitting all ideology dummy variables) to agree with the statement "scientists are generally more objective than others involved in natural resource management decisions" (Model A) and to agree with the statement "science provides objective knowledge about the world" (Model B). Liberals are also significantly more likely than moderates and conservative to disagree with the statement "nonscientists can make valid judgments about the same phenomena studied by scientists using different forms of rationality" (Model C).

Conservatives, on the other hand, are significantly less likely than liberals and moderates to agree that science provides objective knowledge about the world (Model B) and more likely to believe that nonscientists can also "make valid judgments about the same phenomena studied by scientists using different forms of rationality" (Model C). Conservatives are also more likely than moderates and liberals to agree with the statement "scientific findings are often biased by interpretations acceptable to the funding source" (Model E). We originally expected liberals to be the most likely to agree with this statement given our previous discussion where many observers on the left and postmodernists see science as reinforcing the existing power structure.

These findings suggest that ideology does indeed play a role in how science and scientists are perceived. Liberals see science and scientists as generally objective and do not believe that nonscientists have the same ability to understand ecological research, while conservatives are more suspicious of scientific objectivity and believe that nonscientists can 
Table 4. Regression estimates for orientations toward science and scientists

\begin{tabular}{|c|c|c|c|c|c|}
\hline \multirow[b]{2}{*}{ Variables } & \multicolumn{5}{|c|}{ Statements about science ${ }^{a}$} \\
\hline & $\begin{array}{l}\text { A } \\
\text { Scientists are } \\
\text { more } \\
\text { objective } \\
\text { Coefficient } \\
\text { (S.E.) }\end{array}$ & $\begin{array}{l}\text { B } \\
\text { Science } \\
\text { provides } \\
\text { objective } \\
\text { knowledge } \\
\text { Coefficient } \\
\text { (S.E.) }\end{array}$ & $\begin{array}{l}\text { C } \\
\text { Nonscientists } \\
\text { can make } \\
\text { valid } \\
\text { judgments } \\
\text { Coefficient } \\
\text { (S.E.) }\end{array}$ & $\begin{array}{l}\text { D } \\
\text { Methods } \\
\text { support } \\
\text { existing power } \\
\text { structures } \\
\text { Coefficient } \\
\text { (S.E.) }\end{array}$ & $\begin{array}{l}\text { E } \\
\text { Findings } \\
\text { biased by } \\
\text { funding } \\
\text { sources } \\
\text { Coefficient } \\
\text { (S.E.) }\end{array}$ \\
\hline Age & $\begin{array}{c}.009 \\
(.006)\end{array}$ & $\begin{array}{l}.015 * * * \\
(.005)\end{array}$ & $\begin{array}{c}-.014 \\
(.006)\end{array}$ & $\begin{array}{c}.001 \\
(.006)\end{array}$ & $\begin{array}{c}-.009 \\
(.007)\end{array}$ \\
\hline Gender & $\begin{array}{c}-.161 \\
(.125)\end{array}$ & $\begin{array}{c}-.111 \\
(.101)\end{array}$ & $\begin{array}{c}-.075 \\
(.117)\end{array}$ & $\begin{array}{c}.084 \\
(.119)\end{array}$ & $\begin{array}{l}.112 \\
(.129)\end{array}$ \\
\hline Education & $\begin{array}{c}.060 \\
(.160)\end{array}$ & $\begin{array}{c}-.052 \\
(.149)\end{array}$ & $\begin{array}{c}.043 \\
(.156)\end{array}$ & $\begin{array}{c}.029 \\
(.157)\end{array}$ & $\begin{array}{c}.125 \\
(.163)\end{array}$ \\
\hline Liberal & $\begin{array}{l}.232^{*} \\
(.101)\end{array}$ & $\begin{array}{l}.616^{* * * *} \\
(.100)\end{array}$ & $\begin{array}{c}-.287^{*} \\
(.115)\end{array}$ & $\begin{array}{c}.055 \\
(.117)\end{array}$ & $\begin{array}{l}-.115 \\
(.115)\end{array}$ \\
\hline Conservative & $\begin{array}{c}-.107 \\
(.115)\end{array}$ & $\begin{array}{c}-.343^{* *} \\
(.130)\end{array}$ & $\begin{array}{l}.728 * * * \\
(.165)\end{array}$ & $\begin{array}{c}-.170 \\
(.168)\end{array}$ & $\begin{array}{l}.614^{* * * *} \\
(.190)\end{array}$ \\
\hline Managers & $\begin{array}{l}-.169 \\
(.129)\end{array}$ & $\begin{array}{c}-.136 \\
(.115)\end{array}$ & $\begin{array}{l}.524 * * * \\
(.112)\end{array}$ & $\begin{array}{l}.207 \\
(.110)\end{array}$ & $\begin{array}{c}.188 \\
(.111)\end{array}$ \\
\hline Interest groups & $\begin{array}{l}.215 \\
(.146)\end{array}$ & $\begin{array}{l}.302^{* * *} \\
(.118)\end{array}$ & $\begin{array}{l}.802 * * * \\
(.138)\end{array}$ & $\begin{array}{l}.324^{*} \\
(.122)\end{array}$ & $\begin{array}{l}.169 \\
(.149)\end{array}$ \\
\hline Atten. public & $\begin{array}{l}.614 * * * \\
(.178)\end{array}$ & $\begin{array}{l}.573 * * * \\
(.124)\end{array}$ & $\begin{array}{l}.597 * * * \\
(.139)\end{array}$ & $\begin{array}{l}.302 * \\
(.138)\end{array}$ & $\begin{array}{l}-.461 \\
(.132)\end{array}$ \\
\hline Gen. public & $\begin{array}{l}.587 * * * \\
(.119)\end{array}$ & $\begin{array}{l}.623 * * * \\
(.117)\end{array}$ & $\begin{array}{l}.621^{* * *} \\
(.119)\end{array}$ & $\begin{array}{l}.122 \\
(.122)\end{array}$ & $\begin{array}{c}-.342^{*} \\
(.118)\end{array}$ \\
\hline F-test & $8.456 * * *$ & $10.934 * * *$ & $11.826^{* * *}$ & $5.223^{*}$ & $6.351^{*}$ \\
\hline Adj. $R^{2}$ & .10 & .18 & .19 & .04 & .06 \\
\hline$N$ & 1,589 & 1,590 & 1,589 & 1,591 & 1,590 \\
\hline
\end{tabular}

Significance levels: $* p \leq .05 ; * * p \leq .01 ; * * * p \leq .001$.

${ }^{\text {a }}$ See Table 3.

make just as valid observations as scientists. The findings for conservatives support much of the previously discussed literature and critiques of the conservative George W. Bush administration's orientation toward science and scientists. However, we must offer a caveat at this time. The study was conducted in the Pacific Northwest, which has a history of consistently left of center voting records (i.e., "blue" states) and progressive politics (Steel and Lach, 2005) and therefore may not be representative of other regions. We do have preliminary findings, however, from a national survey that suggest similar results to the ones reported here for scientists (Lach et al., 2005).

As for the other variables in the model, the sociodemographic control variables were for the most part not related to attitudes toward science and scientists (with one exception-age in Model B). Many of the dummy variables for the various groups included in the study were significant. However, the purpose of this study was not to focus on group differences but on the impact of ideology on attitudes toward science and scientists in general and within studied groups. Findings in this paper and in previous research on the topic reveal significant differences among scientists, natural resource managers, and the public in the Pacific Northwest about what constitutes science and the most suitable role for ecological science and scientists in the policy process (Lach et al., 2003; Steel et al., 2004). Interestingly, scientists in general are the most skeptical group about the objectivity of 
scientific research and about their ability to provide scientific answers to important environmental policy questions. The attentive public was found to be the most optimistic concerning the objectivity of science. However, the extent to which these patterns hold outside of the American Pacific Northwest remains in question.

\section{Conclusion}

A former Regional Director of the National Marine Fisheries Service, Will Stelle, has commented that "most people practice pick-and-choose . . . agenda-driven science in which the quality of the science is judged by the apparent results achieved. This is not biological science but political science" (cited in Blumm, 2002: 327). As we began this paper, the Union of Concerned Scientists has charged the George W. Bush administration with just such an approach to environmental management. And, as we found in the analyses presented here, ideology does appear to affect how our sampled environmental policy participants in the Pacific Northwest perceive the role of science and scientists in natural resource policy.

The implication of these findings for the use of science in the environmental policy process suggests continuing partisan polarization, at least among some ideologues. While moderates and liberals were generally more supportive of science and scientists, many on the right remain skeptical and strongly support the use of nonscientists in the process as well. One variable for which we did not collect data and that appears to be connected to political ideology and therefore attitudes toward science, is that of religion. One of the major programs of fundamentalist religions in the United States has been increased involvement in politics and political decision-making (e.g., Norris et al., 2004; Berger, 1999). The injection of religious values into science policy issues such as stem cell research reflects the postmodern explanation that organizing institutions such as science are likely to be challenged by local knowledge, non-rational decision criteria, and sub-cultural preferences. This suggests that the findings reported here about the influence of ideology on attitudes toward environmental science may also hold true in other policy arenas such as energy, transportation, and climate change where technical and scientific information often play critical roles in framing problems and solutions.

While scientists are expressing shock at the most recent examples of political manipulation of science, social scientists and others have been observing the politicization of science for decades (e.g., Primack and von Hippel, 1974; Dickson, 1984; Beck, 1992). Scientists accused President Nixon, for example, of implying that his scientific advisors supported a research program about supersonic transport (SST) when in fact many had grave concerns that the planes would damage the ozone layer and contribute to climate change. Robert McNamara, Secretary of Defense for Lyndon Johnson, also misrepresented scientific information about anti-ballistic missiles. As described by Dickson, this was a situation "that left many scientists disenchanted with the role they were being placed in as advisers to the executive branch" (1984: 225).

Collingridge and Reeve (1986), however, note a tendency for institutional science and individual scientists to adapt to changing political whims, securing funding by reconfiguring research programs, questions, and methods. As Beck (1992) noted, one of the trade-offs for this "politicization of science" was the "scientization of policy." Since World War II, institutional science in the developed world has itself been involved in the control of research agendas, funding strategies, and distribution of findings. Findings that emerge from these research agendas have been used to rationalize policy and practices that strove to eliminate any "subjective" knowledge — that is, the values, experience, and local knowledge 
of the individuals affected by decisions and policies. Stakeholders, most of whom like the respondents in this study have a strong respect for the practice of science, have been the odd men out in this troika of science, politics, and bureaucracy-forced to engage with policyand decision-makers on quasi-scientific terms on the issues that personally affect their health, livelihoods, and quality of life.

The promotion of "public interest science" in the early 1970s by liberal individuals and groups, directly challenged the increasingly privileged role of science in addressing social and environmental impacts (Primack and von Hippel, 1974). Even though Congress authorized and appropriated funds for the "Science for Citizens" program in 1976, there was little enthusiasm for the idea at the National Science Foundation or among many in the mainstream scientific community who "objected to its activist tone" (Dickson, 1984: 230). The program faded away quietly by the end of the decade. A twenty-first century resurgence of "public interest science" may reflect conservative individuals and groups who are increasingly convinced that their values about the impact of scientific advances such as cloning, genetic modification, and quantum physics are being left out of the decisions.

We believe that scientists need to work with and engage all groups and citizens and particularly those on the right to build the overall level of trust in both science and sciencebased policy. While almost all scientists and most nonscientists believe that scientists should not make policy, there is an emerging preference for an "integrative" approach to science. This "post-normal science" calls for personal involvement by individual research scientists in bureaucratic and public decision-making, providing expertise and promoting specific strategies that they believe are supported by the available scientific knowledge (Ravetz, 1987; Steel and Weber, 2001). Others, such as Kai Lee, have similarly called for a new "civic science" to integrate science and scientists in the policy process (Lee, 1993). While these approaches may put scientists into very uncomfortable situations outside of the laboratory and into the political realm, they will serve to both familiarize nonscientists with the strengths and limitations of science in policymaking and scientists with the "sausagemaking" of policy.

\section{Acknowledgements}

The scientist, non-governmental organization, manager and attentive public surveys were supported by a grant from the National Science Foundation, "Understanding the Changing Role of Scientists and Scientific Information in Natural Resource Decision Making: A Pilot Study with the Long Term Environmental Research Program." The general public survey was supported by the Program for Governmental Research and Education, Oregon State University.

\section{Note}

1 The question used was, "What is your highest level of education?" The following response categories were provided: (1) never attended school, (2) some grade school, (3) completed grade school, (4) some high school, (5) completed high school, (6) some college, (7) completed college, (8) some graduate school, (9) an advanced degree.

\section{References}

Alm, L. (1997-98) "Lost Credibility? Scientists, Advocacy and Acid Rain,” Journal of Environmental Systems 26: 249-63.

Bailey, R. (1993) Eco-Scam: The Prophets of Ecological Apocalypse. New York: St. Martin's Press.

Beck, U. (1992) Risk Society: Towards a New Modernity. London: SAGE. 
Berger, P. (ed.) (1999) The Secularization of the World: Resurgent Religion and World Politics. Washington, DC: Ethics and Public Policy Center.

Blockstein, D. (2002) "How to Lose Your Political Virginity While Keeping Your Scientific Credibility," Bioscience 52: 91-6.

Blumm, M. (2002) Sacrificing Salmon: A Legal and Policy History of the Decline of Columbia Basin Salmon. Portland, OR: BookWorld Publications.

Bolch, B. and Lyons, H. (1993) Apocalypse Not: Science, Economics, and Environmentalism. Washington, DC: The Cato Institute.

Budiansky, S. (1995) Nature's Keepers: The Science of Nature Management. New York: Free Press.

Collingridge, D. and Reeve, C. (1986) Science Speaks to Power: The Role of Experts in Policymaking. New York: St. Martin's Press.

Devine, R. (2004) Bush versus the Environment. New York: Anchor Books.

Dickson, D. (1984) The New Politics of Science. New York: Pantheon Books.

Dolbeare, K. and Medcalf, L. (1993) American Ideologies Today, 2nd edn. New York: McGraw-Hill.

Dunlap, R. and Michelson, W. (2001) Handbook of Environmental Sociology. Westport, CT: Greenwood Press.

Dunlap, R., Xiao, C. and McCright, A. (2001) "Politics and Environment in America: Partisan and Ideological Cleavages in Public Support for Environmentalism," Environmental Politics 10: 23-48.

Easterbrook, G. (1995) A Moment on the Earth: The Coming of Environmental Optimism. New York: Viking Press.

Ehrlich, P. and Ehrlich, A. (1996) Betrayal of Science and Reason: How Anti-Environmental Rhetoric Threatens Our Future. Washington, DC: Island Press.

Ezrahi, Y. (1980) "Utopian and Pragmatic Rationalism: The Political Context of Scientific Advice," Minerva: A Review of Science, Learning, and Policy 18: 111-31.

FEMAT (1993) Ecosystem Management: An Ecological, Economic, and Social Assessment. Washington, DC: US Government Printing Office.

Fleishman, J. (1986) "Trends in Self-Identified Ideology from 1972 to 1982: No Support for the Salience Hypothesis," American Journal of Political Science 30: 517-54.

Funtowicz, S. and Ravetz, J. (1992) "Three Types of Risk Assessment and the Emergence of Post-Normal Science," in S. Krimisky and D. Golding (eds) Social Theories of Risk, pp. 251-73. Westport, CT: Praeger.

Gardner, G. and Stern, P. (2002) Environmental Problems and Human Behavior, 2nd edn. Boston: Pearson Publishing.

Harmon, W. (1998) Global Mind Change: The Promise of the Twenty-first Century. San Francisco: Berrett-Koehler Publishers.

Helvarg, D. (1994) The War Against the Greens: The "Wise Use" Movement, the New Right, and AntiEnvironmental Violence. San Francisco: Sierra Club Books.

Jones, N. (2002) "Science: The Newest Political Football in the Endangered Species Game," Bioscience 52: 92.

Knight, K. (1993) "Liberalism and Conservatism," in J. Robinson, P. Shaver and L. Wrightsman (eds) Measures of Political Attitudes, pp. 59-158. New York: Academic Press.

Kuhn, T. (1970) The Structure of Scientific Revolutions. Chicago: University of Chicago Press.

Lach, D., List, P., Steel, B. and Shindler, B. (2003) "Advocacy and Credibility of Ecological Scientists in Resource Decision-Making: A Regional Study,” Bioscience 53: 171-9.

Lach, D., Steel, B. and Shindler, B. (2005) "The Role of Science in Natural Resource Decision-Making: A Survey of LTER Scientists," Preliminary Report by the Program for Governmental Research and Education. Corvallis, OR: Oregon State University.

Lee, K. (1993) Compass and Gyroscope. Washington, DC: Island Press.

Levien, R. (1979) "Global Problems: The Role of International Science and Technology Organizations," in J. Gvishiani (ed.) Science, Technology and Global Problems, pp. 45-50. Oxford: Pergamon Press.

Lomborg, B. (1998) The Skeptical Environmentalist: Measuring the Real State of the World. Cambridge: Cambridge University Press.

Luoma, J. (1999) The Hidden Forest: The Biography of an Ecosystem. New York: Henry Holt and Company.

Lyotard, J.F. (1984) The Post Modern Condition: A Report on Knowledge, trans. G. Bennington and B. Massumi. Minneapolis, MN: University of Minnesota Press.

Mann, C. and Plummer, M. (1995) Noah's Choice: The Future of Endangered Species. New York: Alfred Knopf.

Norris, P., Inglehart, R., Leege, D. and Wald, K. (2004) Sacred and Secular; Religion and Politics Worldwide. Cambridge: Cambridge University Press.

Pierce, J., Steger, M.A., Steel, B. and Lovrich, N. (1992) Citizens, Political Communication, and Interest Groups: Environmental Organizations in Canada and the United States. New York: Praeger. 
Popper, K. (1961) The Poverty of Historicism. London: Routledge.

Popper, K. (1972) Objective Knowledge: an Evolutionary Approach. Oxford: Clarendon Press.

Porritt, J. (1985) Seeing Green: The Politics of Ecology Explained. Oxford: Basil Blackwell.

Porritt, J. (2000) Playing Safe: Science and the Environment. New York: Thames and Hudson.

Primack, J. and von Hippel, F. (1974) Advise and Dissent: Scientists in the Political Arena. New York: Basic Books.

Ravetz, J. (1987) “Uncertainty, Ignorance, and Policy," in H. Brooks and C. Cooper (eds) Science for Public Policy, pp. 48-63. New York: Pergamon Press.

Ravetz, J. (1990) The Merger of Knowledge with Power: Essays in Critical Science. London: Mansell Publishing.

Ross, A. (1996) Science Wars. Durham, NC: Duke University Press.

Sarewitz, D. and Pielke, R. (2000) "Prediction in Science and Policy," in D. Sarewitz, R. Pielke and R. Byerly (eds) Prediction: Science, Decision Making and the Future of Nature, pp. 11-22. Washington, DC: Island Press.

Schumacher, E.F. (1973) Small is Beautiful: Economics as if People Mattered. London: Abacus.

Shabecoff, P. (2000) Earth Rising: American Environmentalism in the 21st Century. Washington, DC: Island Press.

Steel, B. and Lach, D. (2005) "Environmental Policy," in R. Clucas, M. Henkels and B. Steel (eds) Oregon Politics and Government: Progressive versus Conservative Populists, pp. 225-41. Lincoln, NE: University of Nebraska Press.

Steel, B. and Weber, E. (2001) "Ecosystem Management, Devolution, and Public Opinion,” Global Environmental Change 11: 119-31.

Steel, B., List, P., Lach, D. and Shindler, B. (2004) "The Role of Scientists in the Environmental Policy Process: A Case Study from the American West," Environmental Science and Policy 7: 1-13.

Union of Concerned Scientists (2004) Scientific Integrity in Policymaking: An Investigation into the Bush Administration's Misuse of Science. Cambridge, MA: Union of Concerned Scientists.

Wildavsky, A. (1995) But Is It True? A Citizen's Guide to Environmental Health and Safety Issues. Cambridge, MA: Harvard University Press.

Wilkinson, T. (1998) Science Under Siege: The Politicians' War on Nature and Truth. Boulder, CO: Johnson Books.

\section{Authors}

Brent S. Steel is Professor of Political Science and Director of the Master of Public Policy Program at Oregon State University. He is the editor of Public Lands Management in the West (1997), co-editor of Global Environmental Policy and Administration (1999), and coauthor of Environmental Politics and Policy: A Comparative Perspective (2003). Correspondence: Brent Steel, Department of Political Science, Oregon State University, 307 Gilkey Hall, Corvallis, Oregon 97331-6206, USA, e-mail: bsteel@oregonstate.edu

Denise Lach is Associate Professor of Sociology and Co-director of the Center for Water and Environmental Sustainability at Oregon State University. Her research and publications focus on environmental issues raised by individuals and organizations, including the use of scientific information in decision-making, stakeholder and citizen involvement, and the role of trust in public acceptability of resource policy.

Vijay A. Satyal is a doctoral student in environmental science at Oregon State University. His work concerns sustainable rangeland management and invasive species. 